\title{
Nrf2-mediated cytoprotective effect of four different hyaluronic acids by molecular weight in human tenocytes
}

\author{
Marialucia Gallorini, Anna C. Berardi, Clarissa Gissi, Amelia Cataldi \& \\ Leonardo Osti
}

To cite this article: Marialucia Gallorini, Anna C. Berardi, Clarissa Gissi, Amelia Cataldi \& Leonardo Osti (2019): Nrf2-mediated cytoprotective effect of four different hyaluronic acids by molecular weight in human tenocytes, Journal of Drug Targeting, DOI: 10.1080/1061186X.2019.1648476

To link to this article: https://doi.org/10.1080/1061186X.2019.1648476

Accepted author version posted online: 24 Jul 2019.

Submit your article to this journal $\llbracket$

山 Article views: 27

View Crossmark data ¿ 
Nrf2-mediated cytoprotective effect of four different hyaluronic acids by molecular weight in human tenocytes

Marialucia Gallorini ${ }^{1}$, Anna C. Berardi ${ }^{2}$, Clarissa Gissi ${ }^{2}$, Amelia Cataldi $^{1}$, Leonardo Osti $^{3}$

${ }^{1}$ Department of Pharmacy, University G. d'Annunzio of Chieti-Pescara, Italy

${ }^{2}$ UOC of Immunohaematology and Transfusion Medicine, Laboratory of Stem Cells, Spirito Santo Hospital, Pescara, Italy

${ }^{3}$ Unit of Arthroscopy and Sports Medicine, Hesperia Hospital, Modena, Italy

* To whom correspondence should be addressed:

Dr. Anna C. Berardi

UOC of Immunohaematology and Transfusion Medicine

Laboratory of Stem Cells, Spirito Santo Hospital

65121-Pescara, Italy

e-mail:

annac.berardi@ausl.pe.it 


\section{ABSTRACT}

Non-traumatic rotator cuff tears (RCTs) are a frequent and potentially disabling injury. There is growing evidence that hyaluronic acid is effective for pain relief and to counteract inflammation in RCTs, however, its effective role in tendinopathies remains poorly studied. The present study aims to disclose a possible molecular mechanism underlying the cytoprotective effects of four different hyaluronic acid preparations (Artrosulfur HA®, Synolis-VA®, Hyalgan ${ }^{\circledR}$ and Hyalubrix $®$ ) under $\mathrm{H}_{2} \mathrm{O}_{2}$-induced oxidative stress. Expression-levels of Lactate dehydrogenase (LDH) released were quantified in cell supernatants, CD44 expression levels were analysed by fluorescence microscopy, the mitochondrial membrane depolarization (TMRE assay) was measured by flow cytometry and the role of the transcription factor Nrf2 was investigated as a potential therapeutic target for RCT treatment. The modulation of extracellular matrix- (ECM) related protein expression (Integrin $\beta 1$, Pro-collagen 1A2 and Collagen 1A1) and autophagy occurrence (Erk 1/2 and phosphoErk 1/2 and LC3B), were all investigated by Western Blot. Results demonstrate that Artrosulfur HA, Hyalubrix and Hyalgan improve cell escape from $\mathrm{H}_{2} \mathrm{O}_{2}$-induced oxidative stress, decreasing cytotoxicity, reducing $\mathrm{Nrf} 2$ expression and enhancing catalase recovery. The present study lays the grounds for further investigations insight novel pharmaceutical strategies targeting key effectors involved in the molecular cascade triggered by hyaluronic acid. 


\section{INTRODUCTION}

Non-traumatic rotator cuff tears are one of the most common musculoskeletal disorders, which results in chronic pain and disability with age-associated incidence and high social costs [1, 2]. Over the last twenty years, a large number of studies has lent support to conservative treatment of tendinopathies using non-invasive therapies and pain management [3, 4, 5]. Unfortunately, a compromised functionality persists with all the currently available approaches, thus research continues to seek innovative pharmacological agent solutions to improve patient outcomes and restore tendon integrity. Disorganization of the Extracellular Matrix (ECM), resulting in collagen fiber disarrangement and inflammation occurrence, has been recognized as a principal cause of pain and dysfunction in RCT pathology, seemingly impeding healing responses [6]. In addition, Sai-Chuen et al. have recently shown that oxidative stress induced by $\mathrm{H}_{2} \mathrm{O}_{2}$ could play some role in failed tendon healing in tendinopathies in an in vivo model [7]. To date, the causal link between the effects of oxidative stress in the degeneration and progressive loss of tendon function is attracting increasing attention in biomedical and clinical research [8]. Moreover, the precise molecular mechanisms underlying RCT pathology are largely unknown and much research into novel therapies to treat tendinopathy is ongoing. A welldefined therapeutic target should be the objective in molecular, cellular, translational and immunebiological research to offer a better outcome to patients.

There is growing evidence that the use of hyaluronic acid (HA) is capable of alleviating pain and improving function in RCTs [9]. However, its effective role in tendinopathies remains poorly studied. HA is a large glycosaminoglycan, which regulates physiological processes in most tissues. HA is a biocompatible, biodegradable and hydrophilic macromolecule which can interact with cell membranes through the so-called "link module" receptors containing a common structural domain of about 100 different amino acids involved in ligand binding. Among them, the cluster of differentiation 44 (CD44) has been the most widely studied $[10,11]$. CD44 is a primary HA receptor with a wide range of 
physiological and pathological functions, which are determined by the protein's extracellular structure and by the very large number of isoforms. One of the most important roles of CD44 is in mediating the uptake and clearance of hyaluronic acid. Furthermore it is a key mediator during normal wound healing, inflammation and fibrotic healing processes. For instance, HA-CD44 interactions promote cell adhesion and motility, thus facilitating tissue repair and remodeling of the injured sites [12]. HA is abundant in tendons and both CD44 and HA levels are elevated during adult tendon healing. Higher levels of HA have been shown to be beneficial in regenerative wound experiments. Despite evidence that HA mitigates tendinopathy through CD44 interaction [13], a previous study [11] found that injured patellar tendons heal better in CD44-deficient mice than in wild type control mice. Furthermore, it has been reported that HA modulates inflammation based on differential degrees of polymerization (i.e. by molecular weight), although the precise effect of variation in molecular-weight of HA on tenocytes in tendinopathy is still unclear. Recently, we have shown that different hyaluronic acid preparations by molecular weight, directly regulate cell activity of tendon-derived cells by enhancing their metabolism and modulating a number of biological processes including cell apoptosis. Indeed we have reported that HA stimulates collagen type I synthesis in a dose-dependent manner, mainly at $1000 \mu \mathrm{g} / \mathrm{ml}[14,15]$. Furthermore, HA has been shown to have a wider range of pharmacological activities, including tissueregenerative and anti-inflammatory properties [16]. It has been reported that HA reduces reactive oxygen species (ROS) production in mechanical-stress-loaded bovine cartilage [17]. Oxidative stress is both beneficial and harmful in biological systems. Cells, and particularly mechano-sensitive musculoskeletal cells such as tenocytes, routinely encounter oxidative stress [18]. It has been widely demonstrated that the accumulation of a large amount of ROS stimulates the intracellular antioxidant system which is accurately regulated by Nrf2 (nuclear factor erythroid 2 [NF-E2]-related factor 2) [19]. It has been reported that a failure of functional tendon-repair may be strongly associated with an excessive inflammatory response which may itself be associated with the activation of the Nrf2 
pathway [20]. Several ongoing studies are seeking to develop specific therapeutic agents to target Nrf2 in order to trigger signaling pathways involved in cell response towards oxidative stress and therefore counteract inflammation [21].

A number of potential intracellular-signaling pathways have functional consequences for tendonpathology environments, such as the regulation of ECM characteristics, immune responses and cell proliferation. Recent studies have shown increased extracellular signal-regulated kinase (Erk 1/2) signalling during tendinopathy and a parallel inhibition of p38, with a consequent reduction in IL6 expression [22]. Separately, Erk 1/2 signalling has been identified as an hallmark in the mechanisms which inhibit tenocyte proliferation and collagen synthesis [23]. Further, it has been shown that Erk inhibitors reduce pro-inflammatory cytokine/chemokine production but do not modulate tenocyte apoptosis in cases of hypoxic tissue stress in human tendinopathy [24, 25].

Another determining factor in the progression of the tendon disease is autophagy which it has been shown to be also involved in adhesion formation [26]. Complementing the Nrf2-dependent regulation of antioxidant responses, the autophagy-lysosomal pathway facilitates additional defense mechanisms against cellular oxidative stress by selectively removing misfolded or damaged intracellular proteins and organelles, and thereby attenuating and reversing the injury caused by oxidative stress [27]. The process of autophagy involves members of the autophagy-related (ATG) family of proteins which regulates the incorporation of phosphatidylinositol 3-phosphate into the phagophore membrane from which autophagosomes are generated. Next, the conjugation of phosphatidylethanolamine to LC3 (MAP1LC3) leads to the formation of the autophagosome-bound form of LC3 called LC3-II [28]. Thus the activation of LC3I into LC3II represents an hallmark of autophagy occurrence [29]. It has been well recognized that mechanical overloading induces cellular stress, such as oxidation and endoplasmatic reticulum disturbance in tenocytes, which contribute to the development of tendinopathy [30]. 
Based on the above observations, we investigated whether HA would be beneficial to human rotatorcuff, tendon-derived cells under induced oxidative stress in vitro. Thus HA potential cytoprotection against hydrogen peroxide-generated damage was here investigated. The antioxidant effects of four different HA by molecular weight on human rotator-cuff tendon-derived cells in terms of cytotoxicity and CD44-HA expression level were studied and, in particular, ECM deposition-related proteins and autophagy occurrence. Finally, the potential role of the Nrf2 signaling pathway in RTCs during HA administration was investigated.

\section{MATERIALS AND METHODS}

\section{Cell culture}

In the current study, cryopreserved, tendon-derived cells, stored in vials in liquid nitrogen, isolated from the same patients used in our previous work were utilized [31]. The tendon-derived cells were thawed out at passage 0 and were immediately used for culture to avoid phenotype drift with further passages. Briefly, tendon samples were previously harvested from healthy areas close to degenerative supraspinatus tendons tear area biopsy specimen in 10 patients who were operated arthroscopically for shoulder rotator cuff repair, with a mean age of $63,6 \pm 6,9$ years. Trauma history, heavy smoking habit or systemic conditions such as thyroid disorders, diabetes, gynecological condition, neoplasia, rheumatic diseases, and any previous or concomitant rotator cuff disease were considered exclusion criteria. Written consent was obtained from the patients prior to surgery and the procedure was approved by the the local authorities. Primary human tendon derived cell cultures were established as previously described $[14,31,32]$.

\section{Cell treatment}

Human tendon-derived cells were seeded as passage 1 in 6 well $\left(0.5 \times 10^{5}\right.$ cells/well $)$ tissue culturetreated plates (Falcon ${ }^{\circledR}$, Corning Incorporated, NY, USA) and let them adhere for 24 hours. In a first set 
of experiments, cultured cells were exposed to $2 \mathrm{mM} \mathrm{H}_{2} \mathrm{O}_{2}$ (stock solution $30 \% \mathrm{v} / \mathrm{v}$, Sigma Aldrich, Milan, Italy) and to four different hyaluronic acid separately, namely Artrosulfur HA® MW 1000, Synolis-VA® MW 2200 KDa, Hyalgan MW 500-730 KDa, and Hyalubrix® MW 1600 KDa (Table 1). The HAs were dissolved, at a final dose of $1000 \mu \mathrm{g} / \mathrm{ml}$ as reported in our previous work [14], in the same culture media used for the entire experiments ( $\alpha$-MEM supplemented with $10 \%$ FBS) and the Ph was adjusted to 7. In a second set of experiments, cells were treated with hyaluronic acids in the presence of $2 \mathrm{mM} \mathrm{H}_{2} \mathrm{O}_{2}$. Untreated cells were used as control. Exposure times varied according to the various parameters analyzed, from 6 hours up to 24 hours.

\section{Lactate dehydrogenase (LDH) release assay}

After the exposure times ( 6 and 24 hours), cell supernatants were collected, centrifugated at $450 x \mathrm{~g}$ for $4 \mathrm{~min}$ and stored on ice. In order to quantify cytotoxicity occurrence, the CytoTox $96^{\circledR}$ NonRadioactive Assay (Promega Corporation, WI, USA) was performed. The CytoTox $96{ }^{\circledR}$ Assay quantitatively measures LDH, a stable cytosolic enzyme that is released upon cell lysis. Released LDH in culture supernatants is measured with a $30 \mathrm{~min}$ coupled enzymatic assay and results were analyzed as previously reported [33].

\section{Immunofluorescence staining of CD44}

Tenocytes were seeded in 4-well chamber slides at $2 \times 10^{4} /$ well $^{\text {(Nunc }}{ }^{\mathrm{TM}}$ Lab-Tek $^{\mathrm{TM}}$ II Chamber Slide ${ }^{\mathrm{TM}}$, Thermo Fisher Scientific, Rochester, NY, USA) in triplicates and cultured as previously described in this section. After 5 minutes (T0), 1 and 3 hours of exposure cell supernatants were discarded and cultures were washed with cold PBS with calcium and magnesium and afterwards fixed with pure acetone for $10 \mathrm{~min}$ at $-20 \mathrm{C}$. Then cells were washed three times with cold PBS and blocked in PBS containing 5\% of Bovine Serum Albumin (BSA; Sigma-Aldrich, Milan, Italy) for 30 minutes at room temperature. After having discarded the blocking solution, tenocytes were incubated with a FITC mouse anti-human CD44 (BD Pharmigen, BD Biosciences, Allschwil, Switzerland) for $1 \mathrm{~h}$ at $37^{\circ} \mathrm{C}$. 
The incubation time was stopped discarding the diluted antibody and washing cultures three times with PBS. Finally, a solution of 4',6-diamidino-2-phenylindole (DAPI; Sigma-Aldrich, Milan, Italy) diluted 1000 times with PBS was added, allowed to stand at room temperature for $5 \mathrm{~min}$ and washed 3 times with deionized water. Slides were examined with a ECLIPSE Ti-U inverted, fluorescent microscope (Nikon Instruments INC., Melville, NY, USA) as previously described [14]. Mean Fluorescence Intensity (MFI) of the negative control was subtracted from that of each sample. The MFI (mean intensity of CD44) fold change was obtained by normalizing MFIs (mean intensity of CD44) to the related untreated cell fluorescence.

\section{Measurement of mitochondrial membrane potential (TMRE assay) by flow cytometry}

After 6 hours of treatment, exposure medium was removed, cells were incubated with TMRE $100 \mathrm{nM}$ (TMRE-Mitochondrial Membrane Potential Assay Kit, Abcam, Cambridge, UK) in PBS/FBS 10\% and were afterwards incubated for 1 hour at $37^{\circ} \mathrm{C}$ in a humified atmosphere. TMRE is a cell permeant, positively-charged, red-orange dye that readily accumulates in active mitochondria due to their relative negative charge. Depolarized or inactive mitochondria have decreased membrane potential and fail to sequester TMRE [34]. Next, cells were washed once with PBS, trypsinized and collected by centrifugation. After having resuspended cells in $300 \mu \mathrm{l}$ of PBS, TMRE fluorescence emission was measured by flow cytometry (CytoFlex flow cytometer, Beckman Coulter, CA, USA) at an excitation wavelength of $488 \mathrm{~nm}$ and an emission wavelength of $575 \mathrm{~nm}$ (TMRE-PE). Negative control represent autoflorescence of unstained cells. Mean Fluorescence Intensity (MFI) were obtained by histogram statistics using the CytExpert Software (Beckman Coulter, CA, USA). Individual values from three independent experiments are summarized as mean values of $\mathrm{MFI} \pm \mathrm{SD}$.

\section{Cell Lysis and Protein Extraction}

After having treated cells for 24 hours as previously described in this section, floating and adherent cells were harvested by trypsinization and collected in cold PBS by centrifugation. Cell 
pellets were washed twice with cold PBS. Lysis buffer $(0.5 \mathrm{ml})$ plus protein inhibitors cocktail (PBS, 1\% IgePal CA-630, 0.5\% sodium deoxycholate, 0.1\% SDS, $10 \mathrm{mg} / \mathrm{ml}$ PMSF, $1 \mathrm{mg} / \mathrm{ml}$ aprotinin, $100 \mathrm{mM}$ sodium orthovanadate and $50 \mu \mathrm{g} / \mathrm{ml}$ leupeptin) was added and set on ice for 30 minutes. The lysed pellets were then re-suspended and kept on ice for a further 30 minutes. Following centrifugation for 15 minutes at 20,000xg, supernatants were collected as whole cell fractions. Protein concentration was determined using a bicinchoninic acid assay (QuantiPro ${ }^{\mathrm{TM}}$ BCA Assay kit for $0.5-30 \mu \mathrm{g} / \mathrm{ml}$ protein, Sigma-Aldrich, Milan, Italy) following the manufacturer's instructions.

\section{Immunoblotting}

Tendon-derived cell lysates (15 $\mu \mathrm{g} / \mathrm{sample})$ were electrophoresed on a 4-20\% SDS-PAGE Gel (ExpressPlus $^{\mathrm{TM}}$ 10x8, GenScript Biotech Corporation, China) and transferred to nitrocellulose membranes. Nitrocellulose membranes were then blocked in $5 \%$ of non-fat milk or $5 \%$ of BSA, $10 \mathrm{mmol} / \mathrm{L}$ Tris $\mathrm{pH} 7.5,100 \mathrm{mM} \mathrm{NaCl}, 0.1 \%$ Tween 20 and probed overnight at $4^{\circ} \mathrm{C}$ under gentle shaking with mouse anti- $\beta$-actin (Sigma-Aldrich, St. Louis, MO, USA) (primary antibodies dilution 1:10,000), mouse monoclonal anti-Integrin $\beta 1$, anti-Pro-collagen $1 \mathrm{~A} 2$ and Collagen $1 \mathrm{~A} 1$ (primary antibody dilutions 1:200) and rabbit polyclonal anti-Nrf2 (primary antibody dilution 1:750) (all purchased by Santa Cruz Biotechnology, CA, USA), rabbit monoclonal anti-Erk 1/2 and anti-phospho-Erk 1/2 (primary antibody dilutions 1:1000) (Cell Signaling Technology, MA, USA) and rabbit monoclonal anti-LC3B (primary antibody dilution 1:1000) (Sigma Aldrich, Milan, Italy) antibodies. Membranes were afterwards incubated in the presence of specific IgG horseradish peroxidase-conjugated secondary antibodies. Immunoreactive bands were identified using the ECL detection system (LiteAblot Extend Chemiluminescent Substrate, EuroClone S.p.a., Milan, Italy) and analysed by densitometry. Densitometric values, expressed as Integrated Optical Intensity (IOI), were estimated in the CHEMIDOC XRS system using the QuantiOne 1-D 
analysis software (BIORAD, Richmond, CA, USA). Values obtained were normalized based on densitometric values of internal $\beta$-actin. Results are expressed as percentages of normalized densitometric values (mean \pm S.D.).

\section{Catalase activity}

The analysis of the antioxidant enzyme catalase activity was carried out in cell supernatants using the Amplex® Red Catalase Assay Kit (Molecular Probes, Invitrogen Corporation, CA, USA) after 24 hour of treatment. Catalase is a heme-containing redox protein which prevents excess of intracellular hydrogen peroxide $\left(\mathrm{H}_{2} \mathrm{O}_{2}\right)$ converting this compound to water and oxygen. In the assay, catalase, if working in samples, first reacts with $\mathrm{H}_{2} \mathrm{O}_{2}$ to produce water and oxygen $\left(\mathrm{O}_{2}\right)$. Next, the Amplex Red reagent reacts with a 1:1 stoichiometry with any unreacted $\mathrm{H}_{2} \mathrm{O}_{2}$ in the presence of horseradish peroxidase (HRP) to produce the highly fluorescent oxidation product, resorufin. Therefore, as catalase activity increases, the signal from resorufin decreases. The absorbance was measured at $560 \mathrm{~nm}$ by means of a spectrophotometer equipped with a microplate reader (Multiskan GO, Thermo Scientific, MA, USA). The results are typically plotted by subtracting the observed fluorescence from that of a no-catalase control (complete growth medium). Assessment of the relative catalase activity $(\mathrm{mU} / \mathrm{ml})$ was calculated using a standard curve generated with specific standards provided by the manufacturers.

\section{Statistics}

Statistical analysis was performed using the analysis of variance (one-way ANOVA) and the pairwise comparison $t$-test. Results were expressed as mean \pm S.D. Values of $p<0.05$ were considered statistically significant. 


\section{RESULTS AND DISCUSSION}

This study demonstrates that the four different HA preparations that we investigated (Artrosulfur HA®, Synolis-VA®, Hyalgan and Hyalubrix $\left.{ }^{\circledR}\right)$ have protective effects against the oxidative stress-related cytotoxicity, induced in vitro by $\mathrm{H}_{2} \mathrm{O}_{2}$, which is a distinctive feature in RCTs. These effects are achieved through the modulation of the hyaluronan receptor CD44, the transcription factor Nrf-2 and the activation of signaling pathways connected to cell survival and autophagy.

It should be noted that the concentrations of HA used $(1000 \mu \mathrm{g} / \mathrm{ml})$ were chosen according to the results obtained from our previous study evaluating dose-response, which used the same HA preparations and tissue samples as used in this study. As shown in Figure 1a, the percentage of LDH released in cell supernatants after 6 and 24 hours reveals that all the HAs administered are noncytotoxic, having viability parameters comparable to those of untreated cultures (both after 6 and 24 hours, mean LDH percentage is comparable to untreated tenocytes, at around $15 \%$ ), which confirms findings of our previous work [14]. By contrast, $2 \mathrm{mM} \mathrm{H}_{2} \mathrm{O}_{2}$ significantly increase the secretion of LDH from tendon-derived cells, registering a peak both after 6 and 24 hours of exposure and representing the highest percentages obseryed in the experimental assay $(98.95 \%$ at 6 hours and 84.24\% at 24 hours). Administration of either Artrosulfur HA, or Hyalubrix or Hyalgan counteracts $\mathrm{H}_{2} \mathrm{O}_{2}$-induced cytotoxicity in tendon-derived cells (Figure 1a). In greater detail, under parallel administration, there is a significant fall in the levels of LDH for these three HA-preparations compared to $\mathrm{H}_{2} \mathrm{O}_{2}$ alone after 6 hours. Moreover, Artrosulfur HA or Hyalubrix are the most effective in restoring membrane integrity in the presence of $\mathrm{H}_{2} \mathrm{O}_{2}$ after 24 hours. However, the LDH released remains relatively high after 24 hours when Hyalgan is administered in parallel with $\mathrm{H}_{2} \mathrm{O}_{2 .}$. As far as Synolis VA is concerned, parallel administration with $\mathrm{H}_{2} \mathrm{O}_{2}$, reduces LDH levels after 6 hours, with respect to $\mathrm{H}_{2} \mathrm{O}_{2}$ alone (51.361\% and $98.954 \%$, respectively). However, over a longer period of 24 hours, its effects are practically indistinguishable from $\mathrm{H}_{2} \mathrm{O}_{2}$ alone (83.942\% and $84.240 \%$, respectively). One 
hypothesis may be that Synolis VA does not act on cytotoxity in the same way as the other HAs do, because of the difference in molecular weight (M.W.), since Synolis VA (2000 kDa) is the HA tested here with the highest M.W. and it has been reported that it affects rheological properties and function. As has been shown in other studies, the amount of anionic charges directly related to the molecular weight of hyaluronic acid could affect the strength of the ionic interaction and the resulting enzymatic activities [35]. Another possible hypothesis is that since Synolis VA contains 4\% sorbitol, this limits HA degradation and may influence its anti-cytotoxic activity. As an indirect cell proliferation analysis, the amount of protein $(\mu \mathrm{g} / \mathrm{ml})$ in the whole cell lysate was quantified by BCA assay (Figure $1 \mathrm{~b}$ ). Briefly, all the HAs administered alone display a protein content comparable to that of the untreated cells $(1389.45 \mu \mathrm{g} / \mathrm{ml})$. As expected, there is a drastic fall in the amount of protein after stimulation with $2 \mathrm{mM} \mathrm{H}_{2} \mathrm{O}_{2}(216.3 \mu \mathrm{g} / \mathrm{ml})$. All the HAs, except Synolis VA, administered in parallel with $\mathrm{H}_{2} \mathrm{O}_{2}$ slightly increase the protein content, while revealing Hyalubrix to be the best preparation $(360 \mu \mathrm{g} / \mathrm{ml})$ at counteracting $\mathrm{H}_{2} \mathrm{O}_{2}$-induced cytotoxicity (Figure $1 \mathrm{~b}$ ).

HA interactions with CD44 cell-surface receptors mediate different biological processes and, consequently, we afterwards investigated each HA preparation-CD44 interaction through the receptor expression profiles in the presence or not of $\mathrm{HA}$ and with or without $\mathrm{H}_{2} \mathrm{O}_{2}$ (Figure 2). Immediately after exposures (T0), the MFI related to Artrosulfur HA dramatically increases compared to untreated cultures (1.99 and 0.61, respectively) resulting in the highest value registered (Figure 2b). After 1 hour of treatment, all the HA preparations significantly up-regulate CD44. The highest peak $(\mathrm{MFI}=4.19)$ is for Synolis-VA, followed by Artrososulfur HA (2.66), Hyalubrix (2.00) and Hyalgan (1.14). After 3 hours of exposure, the fluorescence signal is generally decreased, being Hyalgan the only HA preparation which slightly but significantly up-regulates CD44 with respect to untreated cells (1.60 and 0.88 respectively). Consequently, the MFI fold-change on the untreated control related to HA preparations alone highlights that Artrosulfur HA is effective on CD44 immediately after exposure 
(fold-increase of 4.11 with respect to UC) (Figure 2b, c). Although the MFI fold-change of Artrosulfur HA remains high after 1 hour, the one of Synolis-VA is even more elevated, representing the highest value registered (fold-increase of 12.02 and 7.67, respectively). At the same experimental exposure, CD44 is also significantly up-regulated by Hyalubrix, although to a lesser extent (fold-increase of 5.81). The oxidative stress induced by $\mathrm{H}_{2} \mathrm{O}_{2}$ down-regulates the expression of $\mathrm{CD} 44$, both in terms of MFI (around 0.02 for every experimental exposure) and fold change (Figure 2b, c). In parallel, the presence of all the $\mathrm{HA}$ preparations during $\mathrm{H}_{2} \mathrm{O}_{2}$-exposure increased CD44-expression from that of early exposure times, being even higher than the untreated controls. In details, Artrosulfur HA is the most effective preparation at T0 (MFI 1.27 and fold-change 2.63). After 1 h of exposure in the presence of $\mathrm{H}_{2} \mathrm{O}_{2}$, CD44-expression increases significantly with Artrosulfur HA, Synolis VA (MFI 1.90 with a fold-change of 5.54) and Hyalubrix (MFI 1.72 and fold-change 4.89). In more detail, Artrosulfur HAinduced expression of CD44 remains comparable to T0, whereas Synolis VA induces higher CD44 expression. After 1 h, Hyalgan slightly increases CD44-expression (MFI 0.45 and fold-change 2.17), whereas itis found significantly raised after a 3h exposure (MFI of 2.47 and a fold-change of 2.69). Although CD44 expression remains high at $3 \mathrm{~h}$ for Artrosulfur HA, Synolis VA and Hyalubrix, it is however decreased compared to that at $1 \mathrm{~h}$. Our findings are in accordance with another study that demonstrated CD44 up-regulation by exogenous HA at 4 weeks after surgery in a rotator cuff repair model [36]. Furthermore it has been already revealed that HA modulates cell proliferation and collagen expression in $\mathrm{CD} 44^{+}$tenofibroblasts from rotator cuff tears, favoring tendon healing [37]. Additionally, two studies distinctly reported that Synolis VA and Hyalgan activities were mediated by the CD44 receptor in a human chondrocyte in a in vitro model $[38,39]$. In our experimental model, all the HA preparations increase CD44 levels thus, in accordance with previous studies, it is plausible to assume that they bind to the CD44 receptor and that this interaction (HA-CD44) induces a biological effect by activating signaling via several pathways. Molecular studies have shown that there is a complex 
interplay among the CD44-receptor density, its state of activation and the multivalent binding events, which are all affected by the size of the hyaluronan ligand, which regulate the HA binding at cellsurface [40]. There is a limit beyond which very large hyaluronan molecules become less efficient at engaging multiple receptors due to their steric hindrance, which would suggest that there must be a specific size range (being neither too big nor too small to facilitate binding) which offers maximal biological and molecular response. The existence of isoforms of CD44 may also contribute to the differential HA binding. For HAs of different sizes, differences in the mechanism of action could be more apparent than real. Indeed from a theoretical standpoint, selective binding processes, even for high M.W. HAs, could generate sufficient amounts of HA of the suitable size to trigger a therapeutically-positive biological response [41].

The mitochondrial membrane potential (MMP) was then measured in order to establish the perturbance rate of the intracellular redox equilibrium for $\mathrm{H}_{2} \mathrm{O}_{2}$ and whether or not the recovery seen through the LDH assay could be seen at a mitochondrial level. The TMRE assay was performed after 6 hours of treatment and samples were analyzed by flow cytometry (Figure 3). All four HA preparations alone increase the MFI value compared to untreated cells, and significantly so in the presence of Artrosulfur HA and Synolis-VA. Coherently with LDH data, samples treated with $2 \mathrm{mM} \mathrm{H}_{2} \mathrm{O}_{2}$ undergo dramatic mitochondrial membrane depolarization (MFI $1.08 \times 10^{4}$ ). Surprisingly there is no noticeable variation in MFI values between the four HA preparations administered in parallel with $\mathrm{H}_{2} \mathrm{O}_{2}$ and $\mathrm{H}_{2} \mathrm{O}_{2}$ administered alone $\left(1.2 \times 10^{4}\right.$ and $1.08 \times 10^{4}$, respectively). This demonstrates that co-treatment with any of the HAs does not restore $\mathrm{H}_{2} \mathrm{O}_{2}$-induced mitochondrial membrane depolarization, suggesting that HAs do not prevent mitochondrial disruption in tenocyte-derived tendons. On the other hand, given the absence of HAs protective effect on MMP, it may be that the $\mathrm{H}_{2} \mathrm{O}_{2}$ concentration used here is substantial and mitochondria are rapidly permeable to $\mathrm{H}_{2} \mathrm{O}_{2}$ [42]. Consequently, it is plausible to hypothesise that HAs are not effective at early phases under oxidative stress, but that they are more 
effective over time, despite prompt activation of the CD44 receptor at T0 for Artrosulfur and after 1 and 3 hours for the other HA preparations (Figure 2). This is possibly attributable to the kinetic mechanisms of HA interaction and to the lag time before becoming effective, since the process requires the engagement of membrane receptors involved in inflammation-response and the blocking of related signal transduction pathways [43].

It is well-known that the tendon ECM is mainly composed of collagen, most of which is collagen type I. Tenocytes produce all components of the ECM and participate in cell-cell and cell-matrix interactions mediated via transmembrane signal transduction receptors such as Integrin $\beta 1$. They activate different signal transduction pathways, such as the mitogen-activated protein (MAP) kinase pathway, and thus control proliferation, differentiation and survival of tenocytes [44]. Consequently, we investigated the expression of some of the key molecules in the ECM, namely Integrin $\beta 1$, pro-collagen type I and collagen type I (Fig 4). As shown in Figure 4b, levels of Integrin $\beta 1$ are restored in cells with $\mathrm{H}_{2} \mathrm{O}_{2-}$ induced cytotoxicity in the presence of HAs after 24 hours of treatment. In greater detail, Hyalgan and Hyalubrix administered alone induced significantly increased expression of Integrin $\beta 1$ compared to the untreated control cells. $(62.91 \%, 84.43 \%$ and $53.12 \%$, respectively). The percentage of Integrin $\beta 1$ expression dramatically halves when cells are stimulated with $2 \mathrm{mM} \mathrm{H}_{2} \mathrm{O}_{2}(27.33 \%)$ compared to the untreated control. Notably, the administration of Artrosulfur HA, Hyalgan or Hyalubrix in the presence of $2 \mathrm{mM} \mathrm{H} \mathrm{H}_{2} \mathrm{O}_{2}$ restores Integrin $\beta 1$ protein levels. Moreover, although Synolis-VA administered in parallel with $\mathrm{H}_{2} \mathrm{O}_{2}$ increases the level of Integrin $\beta 1$ expression compared with $\mathrm{H}_{2} \mathrm{O}_{2}$ alone, it does not fully restore Integrin $\beta 1$ expression levels. Studies into other types of connective tissue have shown that the cell-ECM receptor $\beta 1$-integrin mediates cell-ECM interaction as an important pre-requisite for cell survival $[45,46]$ which leads us to hypothesise that a similar mechanism occurs in tendons.

Next we investigated the protein expression levels of pro-collagen type I and collagen type I (Figure 4c). Synolis-VA, Hyalgan or Hyalubrix alone induce a significant increase in pro-collagen I protein 
expression levels compared to the untreated control cells $(89.98 \%, 97.70 \%, 85.82 \%$, respectively versus $77.12 \%$ ), while Artrosulfur $\mathrm{HA}$ does not (67.24\%). $\mathrm{H}_{2} \mathrm{O}_{2}$-induced cytotoxicity significantly increases pro-collagen 1 levels (127.50\%) compared to the untreated control. Parallel administration of Altrosulfur HA, Hyalgan or Hyalubrix, reduces pro-collagen I protein expression levels, although it does not restore expression levels. Synolis-VA does not induce any significant expression-level variation compared to $\mathrm{H}_{2} \mathrm{O}_{2}$ alone (126.72\%). Artrosulfur HA, Synolis-VA or Hyalgan alone induce significantly increased expression of Collagen type I compared to untreated cells (57.50\%, 52.83\%, 49.54\% and 40.64\%, respectively). Hyalubrix induce a slight decrease in expression levels (31.46\%). $\mathrm{H}_{2} \mathrm{O}_{2}$-induced cytotoxicity significantly reduced collagen type 1 expression (23.77\%) compared to the untreated control. All 4 HAs preparations administered in parallel with $\mathrm{H}_{2} \mathrm{O}_{2}$, not only failed to restore collagen type I protein expression levels, but induced a further slight reduction compared to $\mathrm{H}_{2} \mathrm{O}_{2}$ alone $(7.98 \%, 8.94 \%, 10.58 \%$ and $11.43 \%)$. Evaluating the ratio of pro-collagen type I to collagen type I, it should be noted that Hyalubrix alone has the highest ratio value, while Artrosulfur HA alone has a ratio close to 1 (2.72 and 0.85). Synolis VA or Hyalgan alone have ratios which are similar to that of the untreated control $(0.58,0.57$ and 0.52 , respectively). Thus, in the presence of HAs alone the ratio between pro-collagen and collagen production is unremarkable. Moreover, it should be noted that the ratio is higher in favor of mature collagen for Artosulfur HA than in the control, or similar to untreated cells for Synolis-VA and Hyalgan, confirming our previous observations about increased collagen type I production [14]. In the presence of $\mathrm{H}_{2} \mathrm{O}_{2}$-induced cytotoxicity, the ratio of pro-collagen type I to collagen type I increases drastically, because there is a significant increase in pro-collagen type I expression and a significant reduction in collagen type I expression. The co-presence of each of the HA preparations did not reduce this ratio, although for Artrosulfur HA the ratio was slightly lower, because of the lower level of pro-collagen type I expression (Figure 4c). Collagen I consists of two pro-collagen isoforms, $\alpha_{1}$ and $\alpha_{2}$, which are co-translationally translocated into the endoplasmic reticulum (ER). Pro- 
collagen contains pro-peptides at the $\mathrm{C}$ and $\mathrm{N}$ terminal ends which are proteolytically cleaved to integrate with the fibril. Disorganization of the ECM under ER stress during tendon inflammation leads to alteration of pro-collagen trafficking and collagen composition. The delay in restoring the altered collagen 1 ratio was found to be another reason underlying the persistence of RCTs [47]. Moreover it has been reported that hyaluronan modulates cell proliferation and the expression level of pro-collagen alpha1 (III) mRNA, but not expression of pro-collagen alpha1 (I), in fibroblasts from patients with rotator cuff disease, although immunofluorescence cytochemistry detected constitutive binding of HA and CD44 expression [37]. Furthermore, healing process of an injured tendon occurs in three main phases which are inflammatory, reparative (proliferation, characterized by matrix production), remodeling (consolidation and maturation). During the second phases, the ECM is mostly collagen type III which is replaced by collagen type I over the course of the third phase [48]. We may, therefore, hypothesise that HA preparations require longer times than those studied in order to induce collagen type I formation which would then probably contribute to a reduction in healing times. It should, however, be noted that in our study Artrosulfur HA seems to be the most effective among all HA preparations in restoring the pro-collagen I to collagen I ratio in the presence of $\mathrm{H}_{2} \mathrm{O}_{2}$ (Figure 4c).

Molecules involved in oxidative and ER stress cell responses were then analyzed by measuring levels of (the oxidative stress-sensitive factor) Nrf2 and catalase activity as shown in Figure 5a. As expected, $\mathrm{Nrf} 2$ expression is significantly high in cells with $\mathrm{H}_{2} \mathrm{O}_{2}$-induced oxidative stress (47.12\%) compared to the untreated control (16.46\%), whereas Nrf2 levels are significantly lower when HAs are administered in parallel with $\mathrm{H}_{2} \mathrm{O}_{2}$ compared to $\mathrm{H}_{2} \mathrm{O}_{2}$ alone, indicating that all 4 HA preparations induce an antioxidative-stress cell-response (Figure 5a). In greater detail, co-administration of Artrosulfur HA or Hyalubrix results in Nrf2 expression-levels which are only slightly higher than the untreated control (21.47\% and 20.42\%, respectively). Nrf2 expression-levels are lower in the presence of Synolis-VA (14.51\%) than in untreated cells and Hyalgan co-adminstration exhibits similar Nrf2 expression-levels 
$(16.18 \%)$ to the untreated control (Figure 5a). Moreover, Artrosulfur HA or Synolis-VA administered alone, induce significantly higher Nrf2 expression (32.54\% and $29.23 \%$, respectively) than in the untreated control cells, while Hyalgan and Hyalubrix do not influence Nrf2 levels (20.66\% and $15.06 \%$, respectively). As already mentioned, Nrf2 is the major transcription factor involved in the intracellular response towards ROS and thus directly transcripts for antioxidant enzymes such as catalase which is one of the terminal regulators [19]. In our experimental model, in the presence of 2 $\mathrm{mM} \mathrm{H} \mathrm{O}_{2}$, the catalase activity rate is significantly decreased, being half that of untreated cells (300.9 $\mathrm{mU} / \mathrm{ml}$ and $605.6 \mathrm{mU} / \mathrm{ml}$, respectively) (Figure 5b). When the HAs are each administered with $\mathrm{H}_{2} \mathrm{O}_{2}$, the catalase activity rate improves slightly, but significantly, with respect to $\mathrm{H}_{2} \mathrm{O}_{2}$ alone. More in details, with Artosulfur HA and Hyalubrix the rate is slightly higher than for Synolis-VA and Hyalgan (373.1 $\mathrm{mU} / \mathrm{ml}, 369.2 \mathrm{mU} / \mathrm{ml}, 337.6 \mathrm{mU} / \mathrm{ml}$ and $335.1 \mathrm{mU} / \mathrm{ml}$, respectively) revealing them to be the best preparations at inducing catalase activity rate improvement. For the administration of each HA without $\mathrm{H}_{2} \mathrm{O}_{2}$, all the HAs maintain the normal rate of the antioxidant enzyme, with Synolis-VA being a slight but significant inducer, while Hyalgan has a reduced inductive effect $(663.1 \mathrm{mU} / \mathrm{ml}$ and 562.3 $\mathrm{mU} / \mathrm{ml}$ ). Our data suggest that $\mathrm{Nrf} 2$ levels are clearly enhanced by a massive amount of $\mathrm{H}_{2} \mathrm{O}_{2}$, but cell response is not adequate, and is not capable of counteracting oxidative stress, as corroborated by the decreased catalase activity (Figure 5b) and the released LDH values (Figure 1a). On the contrary, when each of the four HA preparations are administered in parallel with $\mathrm{H}_{2} \mathrm{O}_{2}$, Nrf2 expression is largely restored (Figure 5a) and the catalase activity rate is only slightly restored compared to the untreated control, but is significantly restored with respect to the $\mathrm{H}_{2} \mathrm{O}_{2}$ alone. It is plausible to assume that in 2 $\mathrm{mM} \mathrm{H} \mathrm{H}_{2} \mathrm{O}_{2}$-exposed cells, the Nrf2-related molecular cascade fails to activate terminal antioxidant regulators, or catalase dismutation is saturated by the massive concentration of its substrate. By contrast, the presence of HAs leads to constant Nrf2 expression which restores catalase activity and leads to the enhancing of viability as shown by LDH data. 
Nrf2 mRNA is expressed independently of inducers, suggesting a post-transcriptional mechanism, or mechanisms, for Nrf2 activation. Apart from Nrf2 canonical activation through the suppression of its cytoplasmatic inhibitor Keap1 and the consequent nuclear translocation [49], several other mechanisms have been described for the regulation of Nrf2 [50]. In our experimental model, increased levels of total $\mathrm{Nrf} 2$ in the presence of $\mathrm{H}_{2} \mathrm{O}_{2}$ could be due to inhibited proteosomal degradation rather than transcriptional activation due to the high cell permeability towards ROS. Restored cell membrane integrity as shown by LDH data, increased levels of the transduction receptor Integrin $\beta 1$ and the consistent expression of Nrf2, suggest that mechanisms involved in the antioxidant response triggered by the HAs ultimately result in an increase in Nrf2 levels, but also that other molecular machineries are involved which act on a different level to Nrf2 and are probably triggered by the bi-directional receptor Integrin $\beta 1$. Furthermore, Onodera et al have showed that, by adding HA to chondrocytes, they found an HA-induced accumulation of the critical transcriptional factor Nrf2. This led to corresponding changes in expression of target genes, suggesting that the cellular effects of HA are not only due to the HA-CD44binding, but also occur through biological mechanisms and the activation of intracellular signal transduction [51]. As a consequence, proteins which have been reported to be involved in tendon healing during inflammation were investigated. In accordance with with Nrf2 expression findings, Erk $1 / 2$ is slightly activated in untreated control cells with the ratio between the full-length protein and the phosphorylated fraction being 0.42 folds (Figure 6b). All HA preparations enhance Erk 1/2 phosphorylation, Artrosulfur HA and Hyalgan significantly (1.05 and 1.16 fold increase) compared to the untreated control. Conversely, stimulation with $2 \mathrm{mM} \mathrm{H}_{2} \mathrm{O}_{2}$ reduces Erk $1 / 2$ expression to zero. In the presence of Artrosulfur HA, Synolis-VA, Hyalgan or Hyalubrix administered with $\mathrm{H}_{2} \mathrm{O}_{2}$, the pErK $1 / 2$ to ErK $1 / 2$ ratio increases significantly $(1.93,1.90,2.47$ and 3.45 , respectively). The increase in the ratio is higher for Hyalgan and Hyalubrix, as shown in Figure 6 b In our study, increased Erk 1/2 phosphorylation is in accordance with the cytotoxicity data obtained, in that all the HA preparations 
lower the percentage of released LDH when they are each administered with $\mathrm{H}_{2} \mathrm{O}_{2}$, which is not the case for $\mathrm{H}_{2} \mathrm{O}_{2}$ alone. Our results, are in agreement with numerous studies indicating that the activation of Erk1/2 plays a central role in cell survival under a variety of stress stimuli, such as $\mathrm{H}_{2} \mathrm{O}_{2}$, in various tissues, including tendons $[52,53]$.

Finally, in order to establish whether autophagic flux is occurring, the ratio between LC3I and LC3II was quantified after having probed samples by Western blotting (Figure 6a, c, d). The LC3II protein level is only slightly increased in untreated control cells with the LC3I/LC3II ratio assessed at 0.35 , while all the HA preparations used enhance this ratio, but not significantly $(0.87,0.53,0.41,1.04$ for Artrosulfur HA, Synolis-VA, Hyalgan and Hyalubrix respectively). On the contrary, cells under $\mathrm{H}_{2} \mathrm{O}_{2}-$ induced oxidative stress were found to have LC3 I activated, meaning that the LC3II/LC3I ratio is 1.25 fold (Fig. 5d). When tendon-derived cells are exposed to $\mathrm{H}_{2} \mathrm{O}_{2}$ and Artrosulfur HA, Hyalgan or Hyalubrix in parallel, LC3 II expression is significantly higher than for $\mathrm{H}_{2} \mathrm{O}_{2}$ alone $(1.72,1.64,1.28$ and 1.25, respectively), with the highest LC3II/LC3I ratio registered in the presence of Synolis-VA (2.76 fold). The data obtained through the in vitro-model show that, LC3 is activated as a consequence of $\mathrm{H}_{2} \mathrm{O}_{2}$-induced cytotoxicity, confirming cross-talk between inflammation occurrence, ER-stress and autophagy. LC3 activation is higher in $\mathrm{H}_{2} \mathrm{O}_{2}$-stimulated cultures in the presence of HAs, mainly with Synolis-VA (Figure 6d).

\section{CONCLUSIONS}

Data reported here demonstrate that all the HAs administered enhanced cell recovery from $\mathrm{H}_{2} \mathrm{O}_{2}$ exposure, in terms of decreased cytotoxicity and reduced Nrf2 expression. Moreover, a plausible molecular mechanism underlying this cell response is suggested, which appears to be particularly efficient in the presence of Artrosulfur $H A ®$, Hyalgan and Hyalubrix ${ }^{\circledR}$. Furthermore, this study showed increased expression of the HA-receptor CD44 after 1h in the presence of each HA preparation and for Artrosulfur HA® already immediately after exposure (at T0). As illustrated in Figure 7, it 
should be noted that each HA preparation used in this study can trigger a variety of responses, suggesting that they are likely to possess their own specific features. It is plausible to hypothesize that the RCT profile of the candidate patients should be taken into consideration to guarantee the greatest benefit from a potentially personalized HA therapy. The investigation presented here lays the ground for further drug targeting studies in order to discover and better document which aspects of intrinsic HA-product properties and other external factors may influence clinical outcomes, in an effort to improve hyaluronic acid performance on patients in the counteraction of RCTs.

\section{ACKOWLEDGEMENTS}

The authors are grateful for the expert advice about the English usage of the manuscript by Mr. Simon Pool. Part of the project was supported by a Ministry of Education, Research and University (MIUR) grant assigned to Prof. Amelia Cataldi (Fondo FAR 2018).

\section{CONFLICT OF INTEREST}

The authors declare no interest competitions 


\section{REFERENCES}

1. Fehringer EV, Sun J, VanOeveren LS, et al. Full-thickness rotator cuff tear prevalence andvcorrelation with function and co-morbidities in patients sixty-five years and older. J Shoulder Elbow Surg. 2008; 17:881-885.

2. Oliva F, Osti L, Padulo J, et al. Epidemiology of the rotator cuff tears: a new incidence related to thyroid disease. Muscles Ligaments Tendons J. 2014; 4(3):309-14.

3. Loppini M, Maffulli N. Conservative management of tendinopathy: an evidence-based approach. Muscles Ligaments Tendons J. 2012;1(4):134-7.

4. McClinton S, Luedke L, Clewley D. Nonsurgical Management of Midsubstance Achilles Tendinopathy. ClinPodiatr Med Surg. 2017;34(2):137-160.

5. Ryu K, Ko D, Lim G, et al. Ultrasound-Guided Prolotherapy with Polydeoxyribonucleotide for Painful Rotator Cuff Tendinopathy. Pain Res Manag. 2018;2018:8286190.

6. Thankam FG, Roesch ZK, Dilisio MF, et al. Association of Inflammatory Responses and ECM Disorganization with HMGB1 Upregulation and NLRP3 Inflammasome Activation in the Injured RotatorCuff Tendon. Sci Rep. 2018;8(1):8918.

7. Chen S, Jiang S, Zheng W, et al. RelA/p65 inhibition prevents tendon adhesion by modulating inflammation, cell proliferation, and apoptosis. Cell Death and Dis. 2017;8:e2710.

8. Marzetti E, Calvani R, Cesari M, et al.Mitochondrial dysfunction and sarcopenia of aging: from signaling pathways to clinical trials.Int J Biochem Cell Biol. 2013; 45(10):2288-301.

9. Honda H, Gotoh M, Kanazawa T, et al. Hyaluronic Acid Accelerates Tendon-to-Bone Healing After Rotator Cuff Repair. Am J Sports Med. 2017;45(14):3322-3330.

10. Aruffo A, Stamenkovic I, Melnick M, et al. CD44 is the principal cell surface receptor for hyaluronate. Cell. 1990;61(7):1303-13. 
11. Ansorge HL, Beredjiklian PK, Soslowsky LJ. CD44 deficiency improves healing tendon mechanics and increases matrix and cytokine expression in a mouse patellar tendon injury model. J Orthop Res. 2009;27(10):1386-91.

12. Li Y, Jiang D, Liang J, et al. Severe lung fibrosis requires an invasive fibroblast phenotype regulated by hyaluronan and CD44. J Exp Med. 2011;208(7):1459-71.

13. Wu PT, Kuo LC, Su FC, et al. High-molecular-weight hyaluronic acid attenuated matrix metalloproteinase-1 and -3 expression via CD44 in tendinopathy. Sci Rep. 2017;7:40840.

14. Osti L, Berardocco M, di Giacomo V, et al. Hyaluronic acid increases tendon derived cell viability and collagen type I expression in vitro: Comparative study of four different Hyaluronic acid preparations by molecular weight. BMC Musculoskelet Disord. 2015;16:284.

15. Gallorini M, Berardi AC, Berardocco M, et al. Hyaluronic acid increases tendon derived cell viability and proliferation in vitro: comparative study of two different hyaluronic acid preparations by molecular weight. Muscles Ligaments Tendons J. 2017;7(2):208-214.

16. Chen LH, Xue JF, Zheng ZY, et al. Hyaluronic acid, an efficient biomacromolecule for treatment of inflammatory skin and joint diseases: A review of recent developments and critical appraisal of preclinical and clinical investigations. Int J BiolMacromol. 2018;116:572-584.

17. Miki Y, Teramura T, Tomiyama T, et al. Hyaluronan reversed proteoglycan synthesis inhibited by mechanical stress: possible involvement of antioxidant effect. Inflamm. Res. 2010;59, 471-477.

18. Poulsen RC, Knowles HJ, Carr AJ, et al. Cell differentiation versus cell death: extracellular glucose is a key determinant of cell fate following oxidative stress exposure. Cell Death Dis. 2014;5:e1074.

19. Gallorini M, Petzel C, Bolay C, et al. Activation of the Nrf2-regulated antioxidant cell response inhibits HEMA-induced oxidative stress and supports cell viability. Biomaterials. 2015;56:114-28.

20. Meng J, Yu P, Tong J, et al. Hydrogen treatment reduces tendon adhesion and inflammatory response. J Cell Biochem. 2018. 
21. Cuadrado A, Rojo AI, Wells G, et al. Therapeutic targeting of the NRF2 and KEAP1 partnership in chronic diseases. Nat Rev Drug Discov. 2019.

22. Schwartz AJ, Sarver DC, Sugg KB, et al.p38 MAPK signaling in postnatal tendon growth and remodeling. PLoSONE.2015;10(3):e0120044.

23. Poulsen RC, Carr AJ, Hulley PA. Protection against glucocorticoid-induced damage in human tenocytes by modulation of ERK, Akt, and forkhead signaling. Endocrinology 2011;152, 503-514.

24. Millar NL, Reilly JH, Kerr SC, et al. Hypoxia: a critical regulator of early human tendinopathy. Ann Rheum Dis.2012;71(2):302-10.

25. Millar NL, Murrell GA, McInnes IB. Inflammatory mechanisms in tendinopathy- towards translation. Nat Rev Rheumatol. 2017;13(2):110-122.

26. Zheng W, Qian Y, Chen S, et al. Rapamycin Protects Against Peritendinous Fibrosis Through Activation of Autophagy. Front Pharmacol. 2018;9:402.

27. Dodson M, Redmann M, Rajasekaran NS, et al. KEAP1-NRF2 signalling and autophagy in protection against oxidative and reductive proteotoxicity. Biochem J. 2015;469(3):347-55.

28. Boya P, Codogno P, Rodriguez-Muela N. Autophagy in stem cells: repair, remodelling and metabolic reprogramming. Development. 2018;145(4).

29. Huang R, Liu W. Identifying an essential role of nuclear LC3 for autophagy. Autophagy. 2015;11(5):852-3.

30. Chen H, Ge HA, Wu GB, et al. Autophagy Prevents Oxidative Stress-Induced Loss of Self-Renewal Capacity and Stemness in Human Tendon Stem Cells by Reducing ROS Accumulation. Cell Physiol Biochem. 2016;39(6):2227-2238.

31. Oliva F, Berardi AC, Misiti S, et al. Thyroid hormones enhance growth and counteract apoptosis in human tenocytes isolated from rotator cuff tendons. Cell Death Disease. 2013;4:e705. 
32. Yao L, Bestwick CS, Bestwick LA, et al. Phenotypic drift in human tenocyte culture. TissueEng. 2006;12(7):1843-9.

33. Sancilio S, di Giacomo V, Di Giulio M, et al. Biological responses of human gingival fibroblasts (HGFs) in an innovative co-culture model with Streptococcus mitis to thermosets coated with a silver polysaccharide antimicrobial system. PLos One. 2014;9(5):e96520.

34. Chazotte B. Labeling mitochondria with TMRM or TMRE. Cold Spring Harb Protoc. 2011;2011(7):895-7.

35. Kim J, Chang JY, Kim YY, et al. Effects of molecular weight of hyaluronic acid on its viscosity and enzymatic activities of lysozyme and peroxidase. Arch Oral Biol. 2018 May;89:55-64

36. Honda H, Gotoh M, Kanazawa T, et al. Hyaluronic Acid Accelerates Tendon-to-Bone Healing After Rotator Cuff Repair. Am J Sports Med. 2017;45(14):3322-3330.

37. Yamada T, Gotoh M, Nakama K, et al. Effects of hyaluronan on cell proliferation and mRNA expression of procollagens alpha 1 (I) and alpha 1 (III) in tendon-derived fibroblasts from patients with rotator cuff disease: an in vitro study. Am J Sports Med. 2007;35(11):1870-1876.

38. Mongkhon JM, Thach M, Shi Q, et al. Sorbitol-modified hyaluronic acid reduces oxidative stress, apoptosis and mediators of inflammation and catabolism in human osteoarthritic chondrocytes. Inflamm Res.2014; 63(8):691-701.

39. Brun P, Panfilo S, Daga Gordini D, et al. The effect of hyaluronan on CD44-mediated survival of normal and hydroxyl radical-damaged chondrocytes.OsteoarthritisCartilage. 200;11(3):208-16.

40. Lesley J, Hascall VC, Tammi M, et al. Hyaluronan binding by cell surface CD44. J BiolChem. 2000 Sep 1;275(35):26967-75.

41. Guidolin D. Intra-articular 500-730 kDa hyaluronan (Hyalgan®) therapy in the management of osteoarthritis. Can a specific therapeutic profile be defined? Eur Rev Med Pharmacol Sci. 2018 Jul;22(14):4698-4719. 
42. Treberg JR, Braun K, Zacharias P, et al. Multidimensional mitochondrial energetics: Application to the study of electron leak and hydrogen peroxide metabolism. Comp BiochemPhysiol B Biochem Mol Biol. 2018;224:121-128.

43. duSouich P. Absorption, distribution and mechanism of action of SYSADOAS. Pharmacol Ther. 2014;142(3):362-74.

44. van der FlierA, Sonnenberg A. Function and interactions of integrins. Cell Tissue Res. 2001 Sep;305(3):285-98.

45. Cao L, Lee V, Adams ME, et al. beta-Integrin-collagen interaction reduces chondrocyte apoptosis. Matrix Biol. 1999 Aug;18(4):343-55.

46. Hirsch MS, Lunsford LE, Trinkaus-Randall V, et al. Chondrocyte survival and differentiation in situ are integrin mediated. Dev Dyn. 1997 Nov;210(3):249-63.

47. Thankam FG, Dilisio MF, Gross RM, et al. Collagen I: a kingpin for rotator cuff tendon pathology. Am J Transl Res. 2018 Nov 15;10(11):3291-3309.

48. Docheva D, Müller SA, Majewski M, et al. Biologics for tendon repair. Adv Drug Deliv Rev. 2015; 84: 222-239.

49. Wakabayashi N, Itoh K, Wakabayashi J, et al. Keap1-null mutation leads to postnatal lethality due to constitutive Nrf2 activation. Nat Genet. 2003 Nov;35(3):238-45.

50. Ma Q. Role of Nrf2 in Oxidative Stress and Toxicity. Annu Rev Pharmacol Toxicol. 2013;53:40126.

51. Onodera Y, Teramura T, Takehara T, et al. Hyaluronic acid regulates a key redox control factor Nrf2 via phosphorylation of Akt in bovine articular chondrocytes. FEBS Open Bio. 2015; 5:476-84.

52. Dong SQ, Xu HZ, Xia XB, et al. Activation of the ERK 1/2 and STAT3 signaling pathways is required for $661 \mathrm{~W}$ cell survival following oxidant injury. Int J Ophthalmol. 2012;5(2):138-42. 
53. Paxton JZ, Hagerty P, Andrick JJ, et al. Optimizing an intermittent stretch paradigm using ERK1/2 phosphorylation results in increased collagen synthesis in engineered ligaments. Tissue Eng Part A. 2012;18(3-4):277-84.

FIGURE LEGENDS

Figure 1. Lactate dehydrogenase (LDH) release and total protein amount in human tendonderived cell culture in the presence of hyaluronic acids. (a) Bars show the mean percentages \pm SD $(\mathrm{n}=3)$ of LDH released by tenocytes in various experimental situations compared to total LDH released after cell lysis after 6 and 24 hours of exposure. (b) The bar graph displays values \pm SD related to the total amount of proteins obtained by the BCA assay $(n=3)$ after 24 hours of treatment expressed as $\mu \mathrm{g}$ of proteins $/ \mathrm{ml}$ of cell lysate.

**** $\mathrm{p}<0.0001$ between median values of treated samples and Untreated cells after 6 and $24 \mathrm{~h}$.

\#\# $\mathrm{p}<0.01$ between median values of HA-treated samples $+\mathrm{H}_{2} \mathrm{O}_{2}$ and $\mathrm{H}_{2} \mathrm{O}_{2}$ after 6 and $24 \mathrm{~h}$.

\#\#\# $\mathrm{p}<0.005$ between median values of $\mathrm{HA}$-treated samples $+\mathrm{H}_{2} \mathrm{O}_{2}$ and $\mathrm{H}_{2} \mathrm{O}_{2}$ after $6 \mathrm{~h}$.

\#\#\#\# $\mathrm{p}<0.0005$ between median values of $\mathrm{HA}$-treated samples $+\mathrm{H}_{2} \mathrm{O}_{2}$ and $\mathrm{H}_{2} \mathrm{O}_{2}$ after $6 \mathrm{~h}$.

Figure 2. CD44 expression in human tendon-derived cell culture in the presence of hyaluronic acids. (a) Representative images from 3 independent experiments of the expression of CD44 after immunofluorescence staining at 0,1 and 3 hours of culture CD44 is stained in fluorescent green (FITC) and the nuclei are highlighted in fluorescent blue (DAPI). (b) Immunofluorescent quantification by Mean Fluorescence Intensity (MFI). CD44-FITC (green fluorescence) was quantified by anti-CD44 and the total area was measured using a Nikon software. Data are expressed as mean \pm SD from 3 
independent experiments for samples run in triplicate (scale bar: $50 \mu \mathrm{m})$;(c) Values are the mean $( \pm$ SD) of three independent experiments and are reported as the ratio between the MFI of each sample and the MFI of the untreated cells (fold-change).

** $\mathrm{p}<0.05$ between median values of treated samples and Untreated cells.

$* * * \mathrm{p}<0.005$ between median values of HA-treated samples and Untreated cells;

$* * * * \mathrm{p}<0.0001$ between median values of treated samples and Untreated cells.

\#\# $\mathrm{p}<0.01$ between median values of HA-treated samples $+\mathrm{H}_{2} \mathrm{O}_{2}$ and $\mathrm{H}_{2} \mathrm{O}_{2}$.

\#\#\# $\mathrm{p}<0.005$ between median values of $\mathrm{HA}$-treated samples $+\mathrm{H}_{2} \mathrm{O}_{2}$ and $\mathrm{H}_{2} \mathrm{O}_{2}$

\#\#\#\# p<0.0001 between median values of HA-treated samples $+\mathrm{H}_{2} \mathrm{O}_{2}$ and $\mathrm{H}_{2} \mathrm{O}_{2}$

Figure 3. Measurement of the mitochondrial membrane potential (MMP) in human tendonderived cell culture in the presence of hyaluronic acids. The modulation of the MMP measured by flow cytometry is displayed in the bar graph and it is provided as the mean fluorescence intensity $(\mathrm{MFI}) \pm \mathrm{SD}(\mathrm{n}=3)$. Representative fluorescence peaks are shown and are provided to highlight the fluorescence shift in the phycoerythrin channel.

$* * * * \mathrm{p}<0.0001$ between median values of treated samples and Untreated cells.

$* * * \mathrm{p}<0.005$ between median values of HA-treated samples and Untreated cells;

\#\# $\mathrm{p}<0.01$ between median values of HA-treated samples $+\mathrm{H}_{2} \mathrm{O}_{2}$ and $\mathrm{H}_{2} \mathrm{O}_{2}$.

Figure 4. Integrin $\beta 1$, Pro-collagen type 1 and Collagen type 1 protein expression in human tendon-derived cell culture in the presence of hyaluronic acids. (a) Typical results of the analysis of protein expression by Western blotting of at least three independent experiments. $\beta$-actin expression is used as protein content marker. (b, c) Bar graphs display densitometric values expressed as the mean percentage $\pm \operatorname{SD}(n=3)$ of integrated optical densities of protein bands normalized on $\beta$-actin. 
$* * * * \mathrm{p}<0.0001$ between median values of treated samples and Untreated cells.

$* * * \mathrm{p}<0.001$ between median values of treated samples and Untreated cells

** $\mathrm{p}<0.05$ between median values of treated samples and Untreated cells.

\#\# $\mathrm{p}<0.01$ between median values of HA-treated samples $+\mathrm{H}_{2} \mathrm{O}_{2}$ and $\mathrm{H}_{2} \mathrm{O}_{2}$.

\#\#\#\# p<0.0001 between median values of HA-treated samples $+\mathrm{H}_{2} \mathrm{O}_{2}$ and $\mathrm{H}_{2} \mathrm{O}_{2}$

Figure 5. Nrf2 protein expression and catalase activity in human tendon-derived cell culture in the presence of hyaluronic acids. (a) Typical results of the analysis of protein expression by Western blotting of at least three independent experiments. $\beta$-actin expression is used as protein content marker. Bar graphs display densitometric values expressed as the mean percentage \pm SD $(n=3)$ of integrated optical densities of protein bands normalized on $\beta$-actin. (b) Bars display the modulation of catalase activity $(\mathrm{mU} / \mathrm{ml})$ of tenocytes over the different experimental conditions.

\# $\mathrm{p}<0.05$ between median values of HA-treated samples $+\mathrm{H}_{2} \mathrm{O}_{2}$ and $\mathrm{H}_{2} \mathrm{O}_{2}$

$* * * * \mathrm{p}<0.0001$ between median values of treated samples and Untreated cells.

$\# \# \#$ p $<0.0001$ between median values of HA-treated samples $+\mathrm{H}_{2} \mathrm{O} 2$ and $\mathrm{H}_{2} \mathrm{O}_{2}$

Figure 6. Erk 1/2, pErk 1/2 and LC3 I-II protein expression in human tendon-derived cell culture in the presence of hyaluronic acids. (a) Typical results of the analysis of protein expression by Western blotting of at least three independent experiments. $\beta$-actin expression is used as protein content marker. (b, c, d) Bar graphs display densitometric values expressed as the mean percentage \pm SD $(n=3)$ of integrated optical densities of protein bands normalized on $\beta$-actin of the ratio pErk $1 / 2$ and Erk 1/2 (b), LC3I and LC3II relative expression (c) and the ratio LC3II and LC3I (d).

$* \mathrm{p}<0.05$ between median values of treated samples and Untreated cells.

$* * \mathrm{p}<0.01$ between median values of treated samples and Untreated cells. 
$* * * \mathrm{p}<0.005$ between median values of treated samples and Untreated cells.

$* * * * \mathrm{p}<0.0001$ between median values of treated samples and Untreated cells.

\# $\mathrm{p}<0.05$ between median values of HA-treated samples $+\mathrm{H}_{2} \mathrm{O}_{2}$ and $\mathrm{H}_{2} \mathrm{O}_{2}$.

\#\# $\mathrm{p}<0.01$ between median values of HA-treated samples $+\mathrm{H}_{2} \mathrm{O}_{2}$ and $\mathrm{H}_{2} \mathrm{O}_{2}$.

\#\#\#\# p $<0.0001$ between median values of HA-treated samples $+\mathrm{H}_{2} \mathrm{O}_{2}$ and $\mathrm{H}_{2} \mathrm{O}_{2}$

Figure 7. Schematic representation of the most effective HAs at restoring biological and molecular activity after 6 and 24 hours from $\mathrm{H}_{2} \mathrm{O}_{2}$ exposure. 
Figure 1.
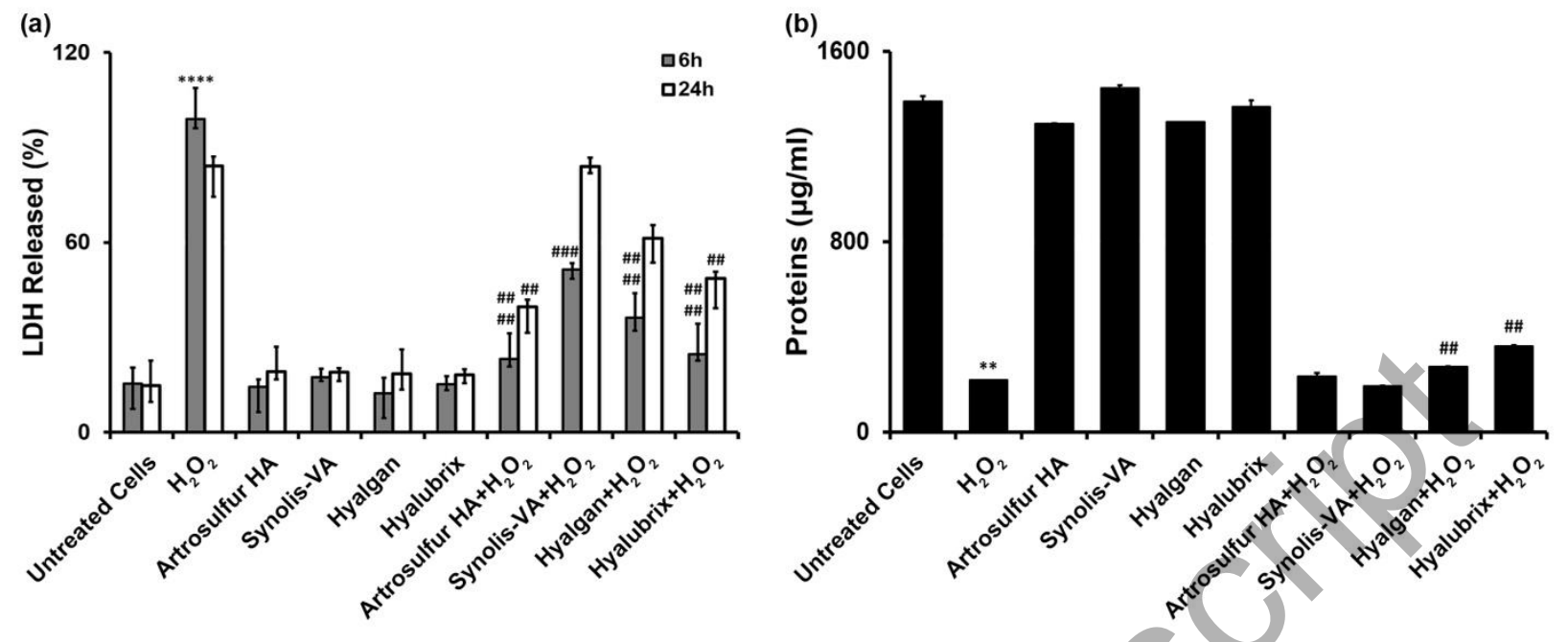
Figure 2.

(a)
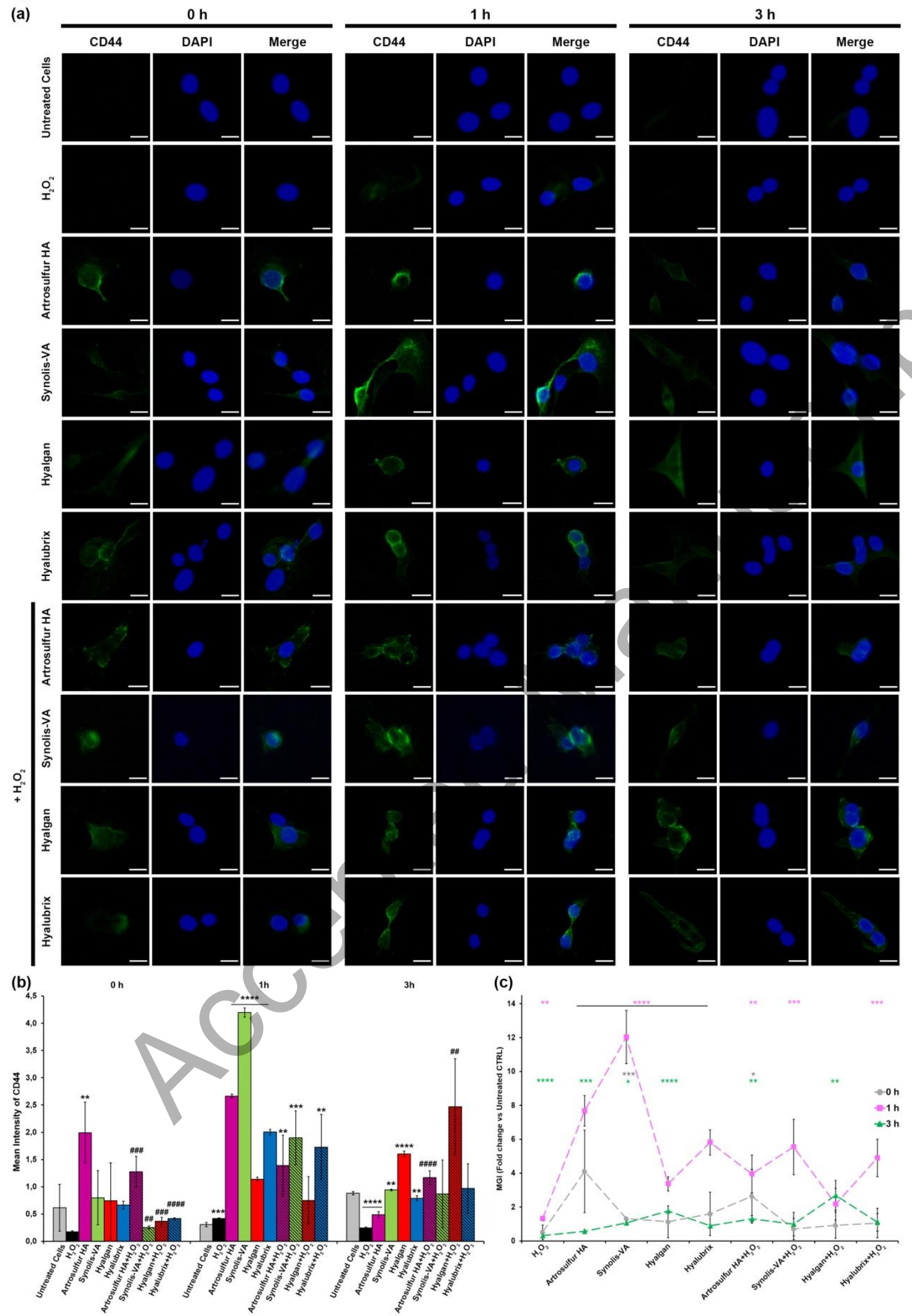

(c)

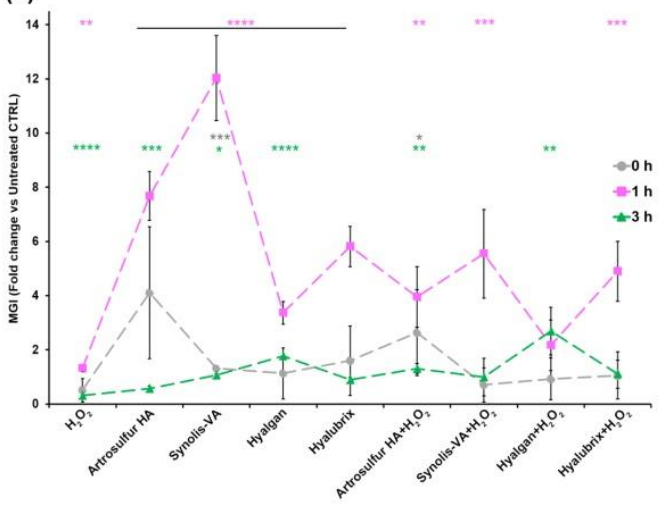


Figure 3.

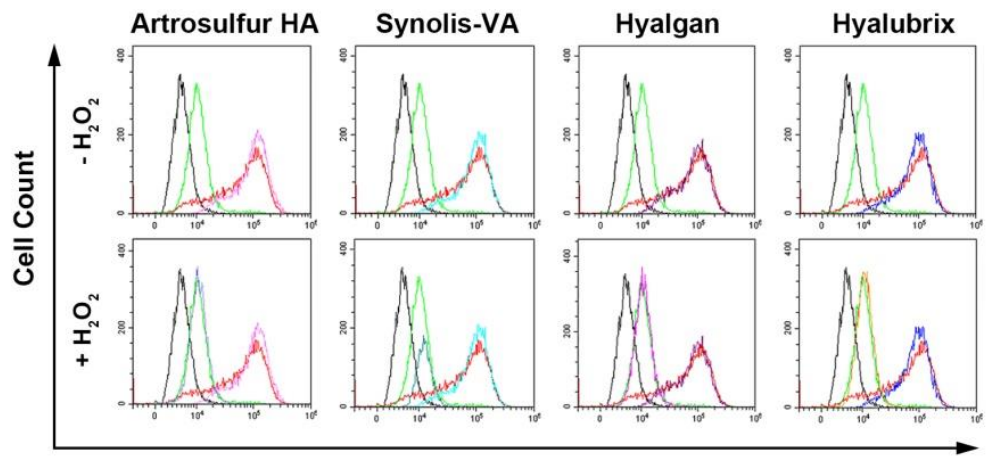

Mitochondrial Membrane Potential (PE)

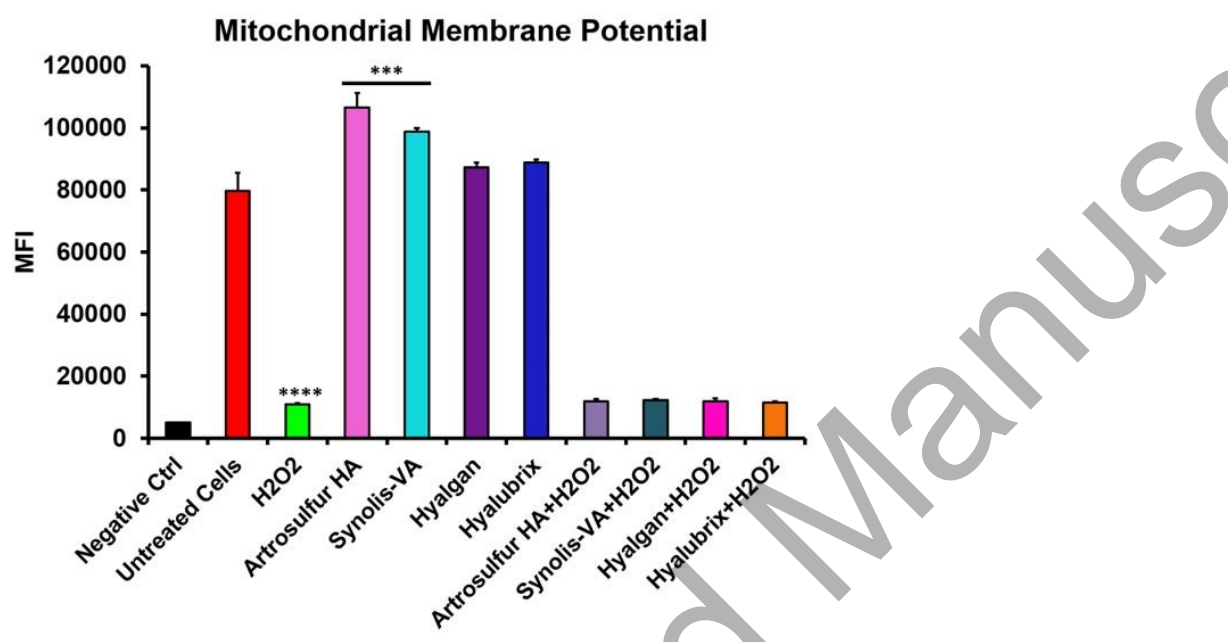


Figure 4.

(a)
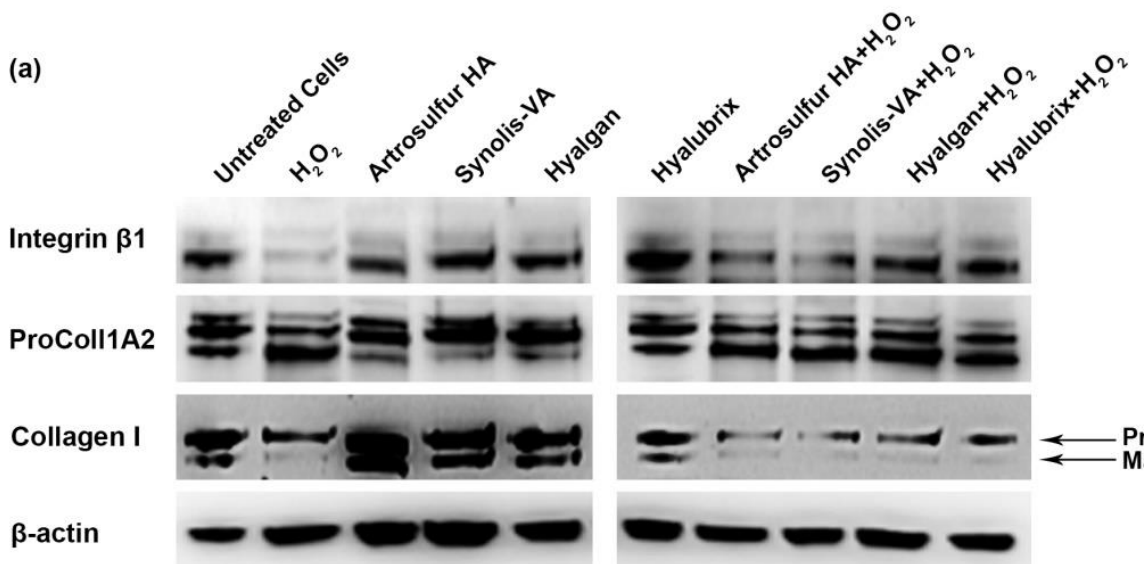

(b)

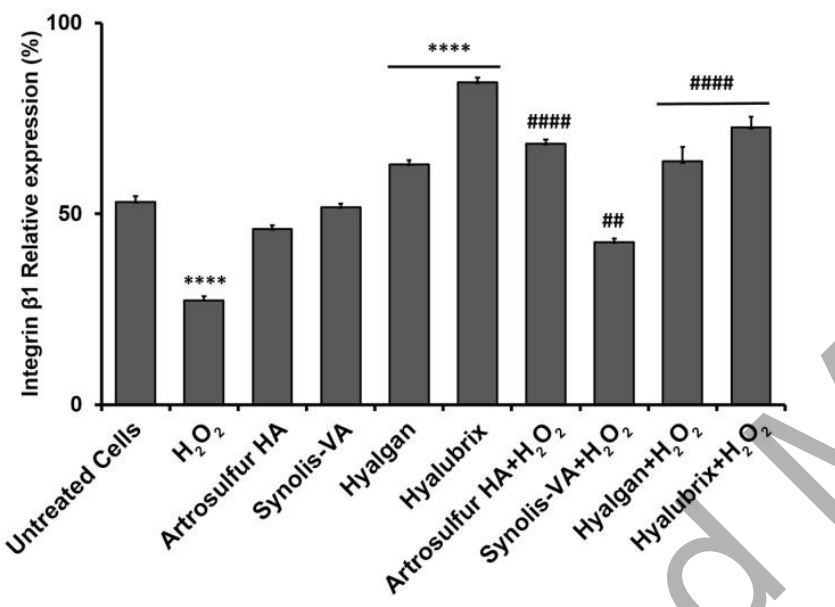

(c)

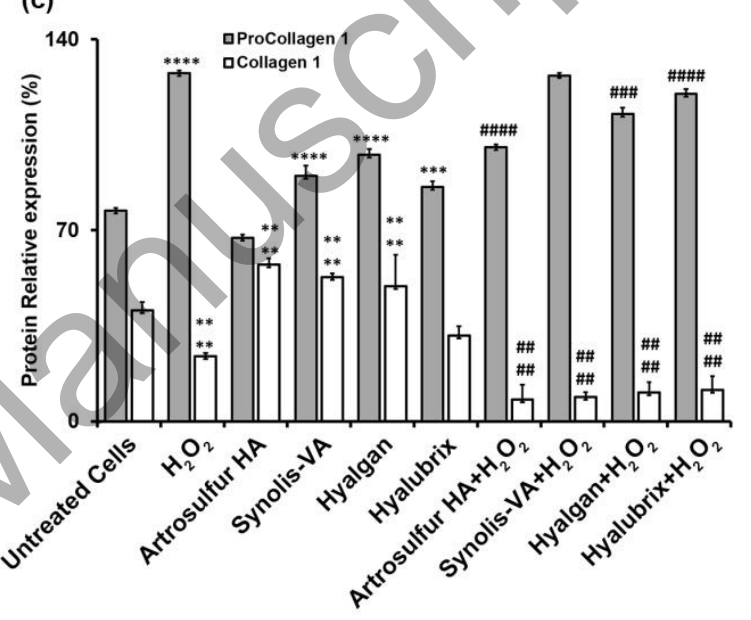


Figure 5.

(a)
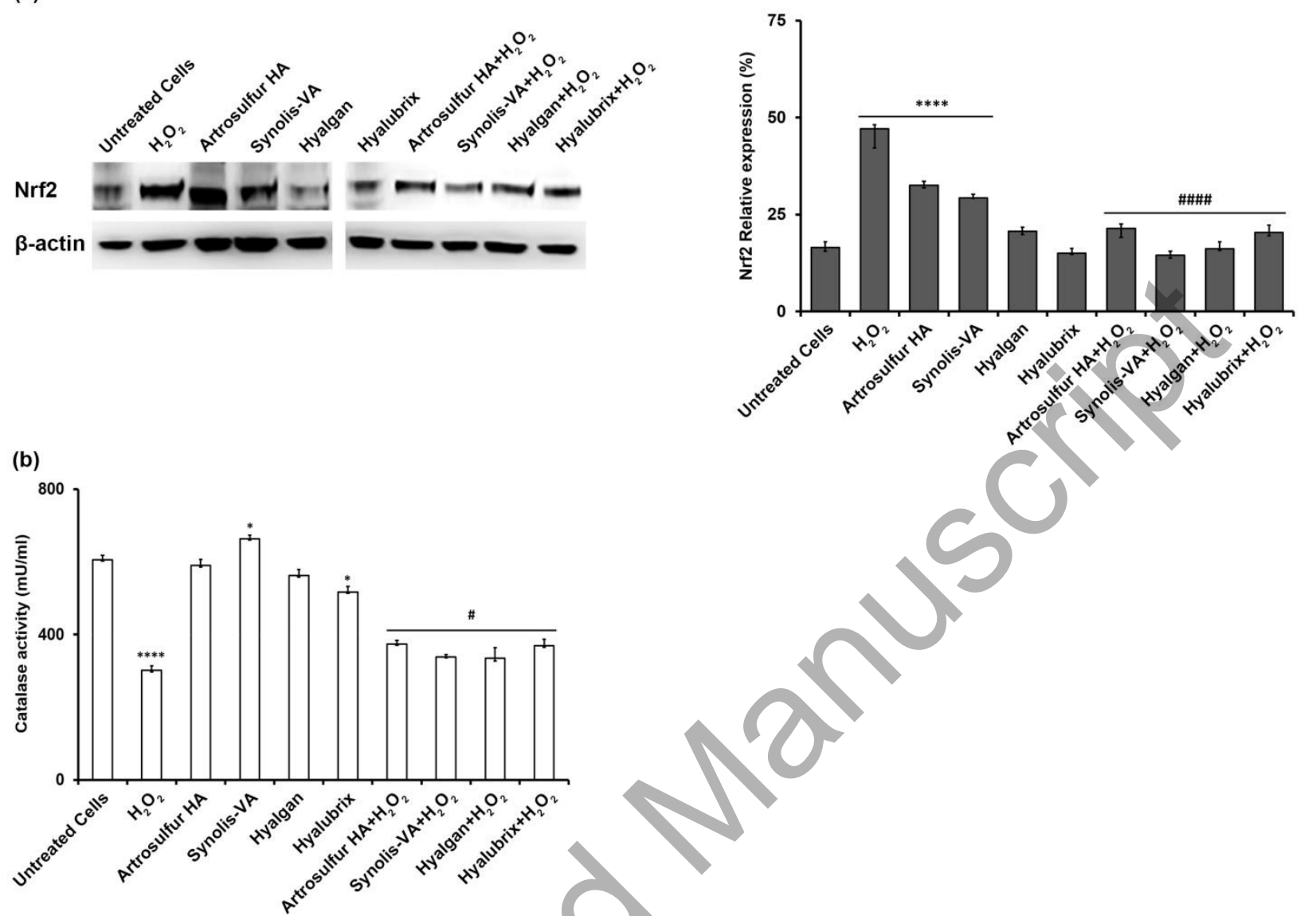
Figure 6.

(a)

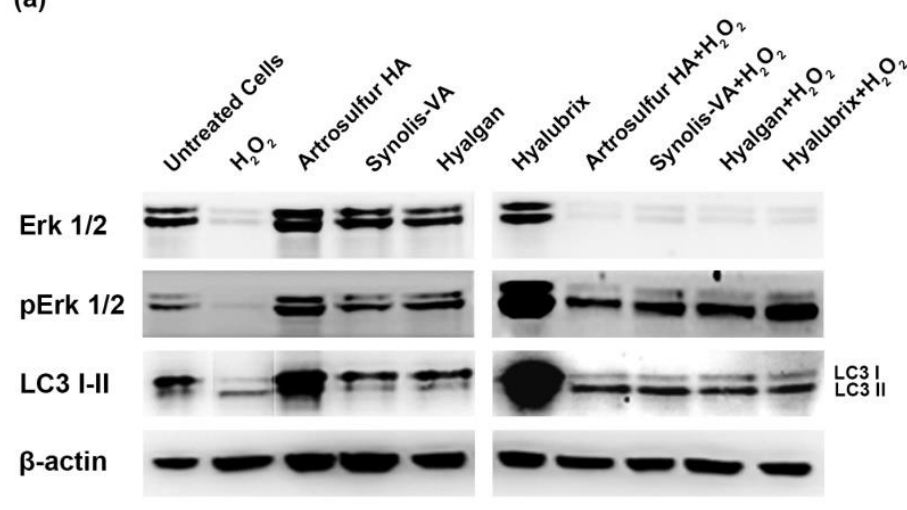

(c)

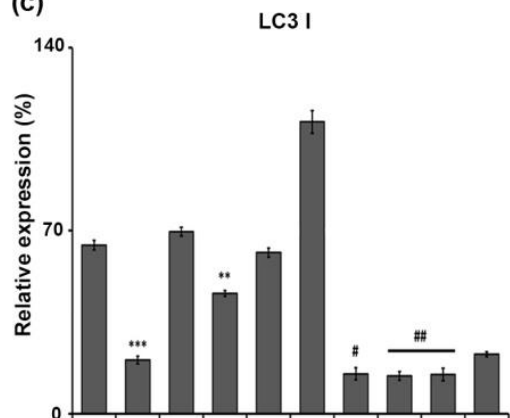

LC3 I

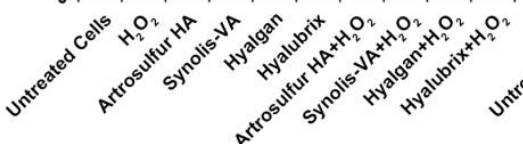

(b)

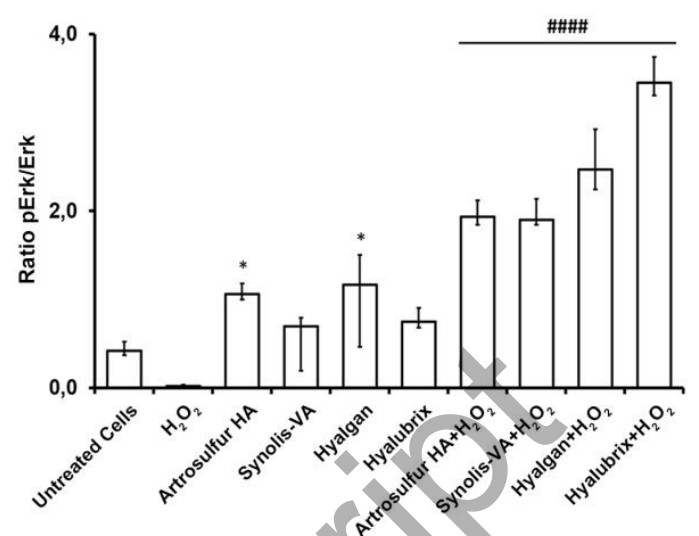

(d)
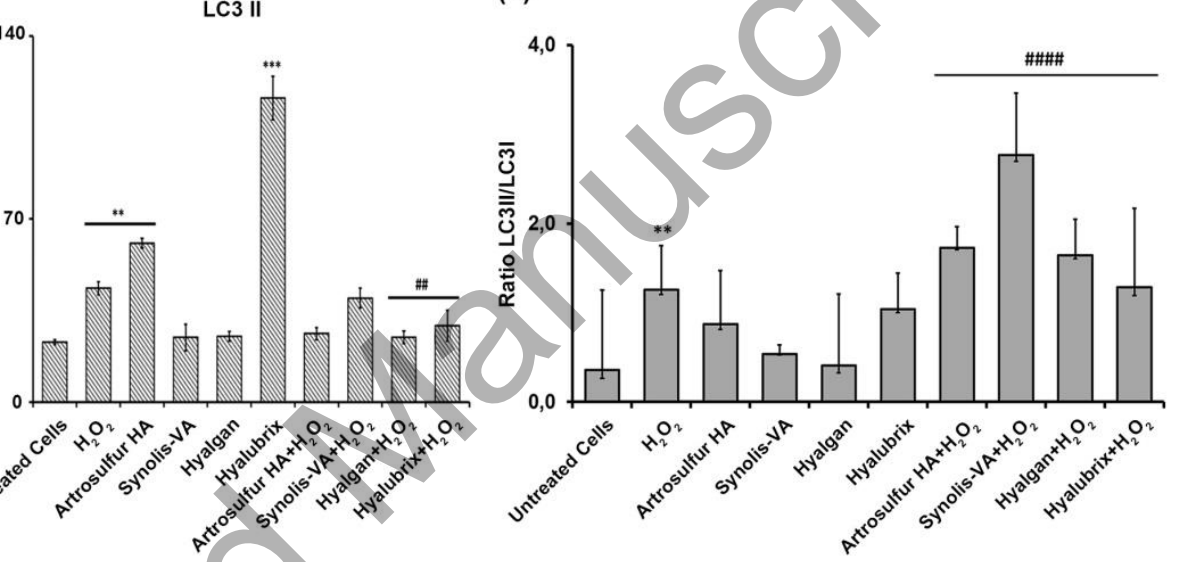


\section{Figure 7.}

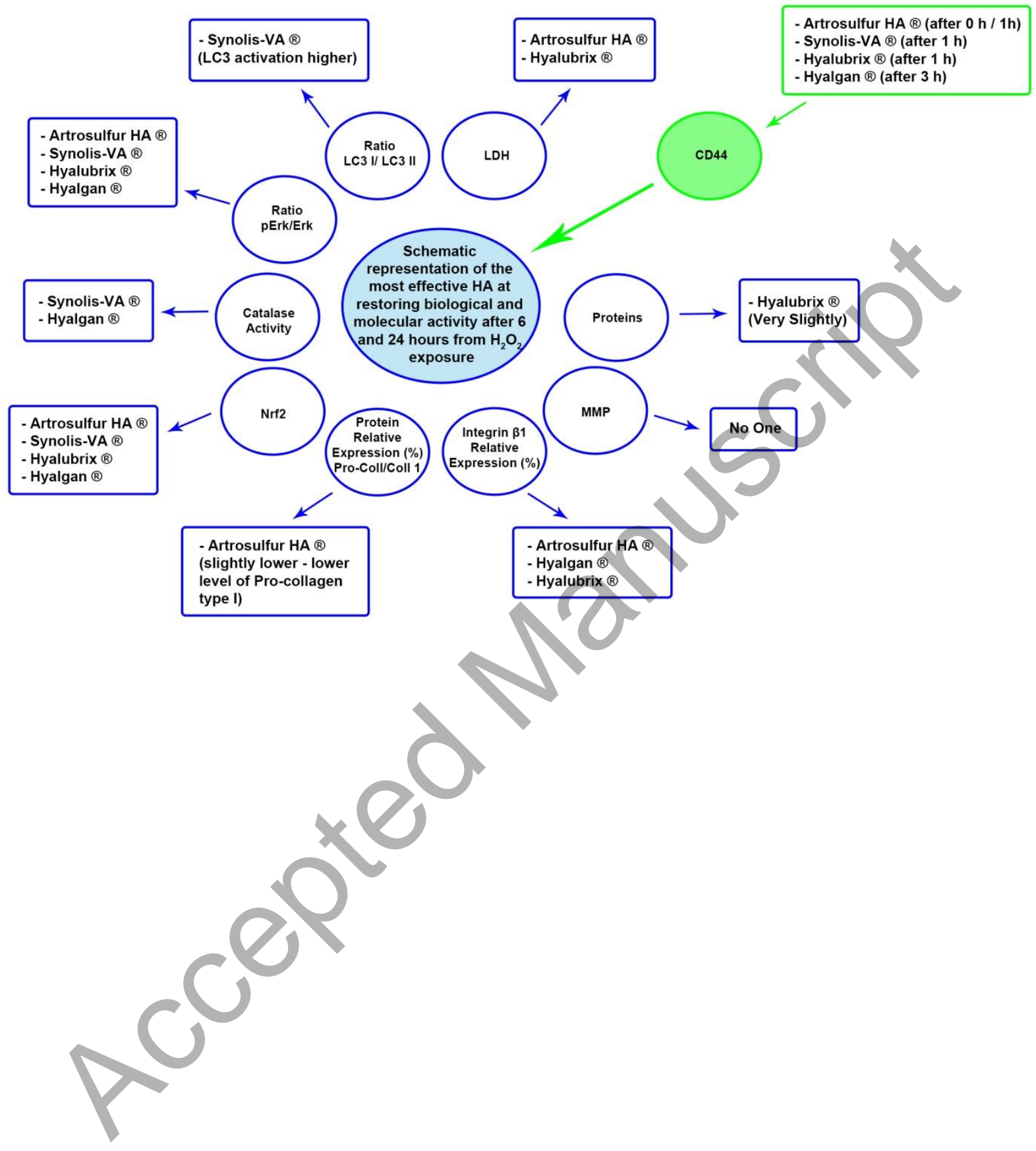


Table 1. Features of Hyaluronic Acids preparations tested

\begin{tabular}{|c|c|c|c|c|}
\hline Commercial Name & Active Substance & $\begin{array}{l}\text { Molecular } \\
\text { Weight }\end{array}$ & Source & Manufacturer \\
\hline Hyalgan ${ }^{\circledR}$ & $\begin{array}{l}\text { Linear Sodium } \\
\text { Hyaluronate }\end{array}$ & 600-730 KDa & $\begin{array}{l}\text { Rooster } \\
\text { Combs }\end{array}$ & $\begin{array}{c}\text { Fidia Farmaceutici } \\
\text { s.p.a., Abano Terme } \\
\text { (PD), Italy }\end{array}$ \\
\hline Artrosulfur HA® & $\begin{array}{c}\text { Linear Sodium } \\
\text { Hyaluronate }\end{array}$ & $1000 \mathrm{KDa}$ & $\begin{array}{c}\text { Bacterial } \\
\text { Fermentation }\end{array}$ & $\begin{array}{l}\text { Laborests.p.a., } \\
\text { Nerviano (MI), Italy }\end{array}$ \\
\hline Hyalubrix ${ }^{\circledR}$ & $\begin{array}{l}\text { Linear Sodium } \\
\text { Hyaluronate }\end{array}$ & $1600 \mathrm{KDa}$ & $\begin{array}{l}\text { Bacterial } \\
\text { Fermentation }\end{array}$ & $\begin{array}{l}\text { Fidia Farmaceutici } \\
\text { s.p.a., Abano Terme } \\
\text { (PD), Italy }\end{array}$ \\
\hline Synolis-VA® & $\begin{array}{c}\text { Linear Sodium } \\
\text { Hyaluronate + Sorbitol } \\
(4 \%) \text { (limits the HA } \\
\text { degradation) }\end{array}$ & $2000 \mathrm{KD}$ & ion & $\begin{array}{c}\text { Anteis s.a., Geneva, } \\
\text { Switzerland }\end{array}$ \\
\hline
\end{tabular}

